\title{
Physicochemical properties of frozen tortillas from nixtamalized maize flours enriched with $\beta$-glucans
}

\author{
Miguel Ángel SÁNCHEZ-MADRIGAL ${ }^{1}$, David NEDER-SUÁREZ1 ${ }^{1}$, Armando QUINTERO-RAMOS ${ }^{1 *}$, \\ Martha Graciela RUIZ-GUTIÉRREZ ${ }^{1}$, Carmen O. MELÉNDEZ-PIZARRO르. Hilda Amelia PIÑÓN-CASTILLO², \\ Tomás GALICIA-GARCÍA ${ }^{1}$, Benjamín RAMÍREZ-WONG ${ }^{3}$
}

\begin{abstract}
Effects of different $\beta$-glucan concentrations in maize flour on the properties of frozen maize tortillas were evaluated. Masa (dough), pre-cooked (PTs), frozen (FTs), thawed (TTs), and cooked tortillas (CTs) were made and analyzed. Moisture content of masa and tortillas significantly decreased as $\beta$-glucan concentration increased; however, the water absorption capacity (WAC), ice melting enthalpy, and frozen water in FTs increased. Texture and color of the masa, PTs, and CTs as well as sensory analysis showed differences only between tortillas with $0 \%$ and $4 \% \beta$-glucans. $\beta$-glucans did not affect the texture of CTs. Soluble fiber increased by over threefold and fivefold in tortillas with $2 \%$ and $4 \% \beta$-glucans, respectively, than in those without $\beta$-glucans. This result was consistent with the observed structural changes in tortillas, showing an increase in high-fiber aggregates with increasing $\beta$-glucan concentration. Tortillas with $2 \% \beta$-glucans showed acceptable physicochemical, functional, and sensory properties, but over three times the soluble fiber. Therefore, it is possible to obtain frozen tortillas with high fiber content and increase their shelf life for subsequent cooking while maintaining good properties.
\end{abstract}

Keywords: maize flours; frozen tortillas, $\beta$-glucans; dietary fiber; soluble fiber.

Practical Application: Nixtamalization is a process through which maize is cooked to obtain mainly instant flours for making tortillas. However, the pericarp removed during this process result in flours with low fiber content. This research presents an alternative to enrich maize flours with $\beta$-glucans to produce high fiber tortillas and frozen to extend their short shelf life as alternative for storage and increase their availability of fresh tortillas. Frozen tortillas with fiber added showed acceptable properties compared to commercial tortillas, but with over triple of soluble fiber.

\section{Introduction}

Maize (Zea mayz L.) is the most produced and consumed cereal in Mexico (Vázquez-Carrillo et al., 2015) in various products derived from nixtamalization process. These products such as tortillas and snacks are obtained mainly of instant maize flours. The preference for instant maize flours and their products is desirable mainly because of their flavor and nutritional benefits. These nixtamalized maize flours are mainly intended for tortilla production, which is considered the base of the daily diet of Mexican people (Osorio-Díaz et al., 2011; Vázquez-Carrillo et al., 2015; Valderrama-Bravo et al., 2015), with an average daily consumption of 1200 million, $40 \%$ of which are made of nixtamalized maize flours (Reyes-Moreno et al., 2013). However, the commercial instant maize flours have low fiber content because of losses during the nixtamalization process. The fiber is naturally contained in the pericarp of the maize grain, but the nixtamalization process causes losses of around 70-90\% (Bressani et al., 2001; Gutiérrez et al., 2007; Palacios-Fonseca et al., 2009).

The current market trend towards the innovation and commercialization of foods to satisfy consumer demands and improve their health has made it possible to develop functional foods from nixtamalized maize flours. Industrially, vitamins and proteins are added while the fiber content of the flour remains low despite its importance and beneficial health effects.

The addition of dietary fiber in nixtamalized maize flours to obtain tortillas is an option to integrate this natural component to this traditional product of high consumption. Dietary fiber is beneficial for health maintenance and disease prevention of consumers, contributes to physiological attenuations, prevents constipation, and facilitates good colonic health (Foschia et al., 2013; Ishida \& Steel, 2014). However, the addition of dietary fiber at maize flours should be done carefully, because it could modify several features such as WAC (Ishida \& Steel, 2014) and starch gelatinization, which could affect thermal and rheological properties of masa, leading to quality changes in tortillas (Cornejo-Villegas et al., 2010; Ramírez-Moreno et al., 2015).

Among the dietary fiber components used in the food industry are $\beta$-glucans (mixed linkage (1-3)(1-4)- $\beta$-D-glucans), which play an important technological role in processed foods (Foschia et al., 2013; Limberger-Bayer et al., 2014). They are 
one of the most valuable sources of dietary fiber in cereal crops (Zhao et al., 2014) and the most abundant component of the soluble fiber fraction in cereals such as barley and oats (Limberger-Bayer et al., 2014). $\beta$-glucans are polysaccharides of $\mathrm{D}$-glucose monomers linked through $\beta$-glycosidic bonds, and the derived from cereals have two or three consecutive $\beta$-(1-4) linkages separated by a single $\beta$-(1-3) linkage (Lazaridou \& Biliaderis, 2007; Zhu et al., 2016). Some reports show that hydroxyl groups of fibers including $\beta$-glucans, interact with water through hydrogen bonding, favoring their capacity to absorb or retain water (Chaplin, 2003; Foschia et al., 2013). This could change the water absorption properties of flours, and secondly compete with starch for water, causing changes in gelatinization, thermal and rheological properties of masa (Cornejo-Villegas et al., 2010; Ramírez-Moreno et al., 2015), which could affect the machinability of masa and tortilla. For this reason is important to determine the appropriate concentration of $\beta$-glucans in maize flour that resulting in flours, masas and tortillas with good quality.

Additionally, the consumption of $\beta$-glucans has many health benefits and prebiotic properties (Zhu et al., 2016). Including prevention of obesity, reduction of the risk of diabetes and colon cancer, and decreasing blood lipids, glucose, and high cholesterol levels (Wood, 2007; Khoury et al., 2012; Kurek et al., 2015).

Following current consumer trends towards healthier diets, many studies have investigated the addition of different components to fortify nixtamalized maize flours and tortillas: chickpea flour (Barrón \& Espinoza, 1993), cowpea flour (Sefa-Dedeh et al., 2003), bean flour (Mora-Avilés et al., 2007), flaxseed flour (Rendón-Villalobos et al., 2009), triticale flour (Vaca-García et al., 2011), and others. Thus, fortifying maize flours is important because as mentioned the nixtamalization process removes a high percentage of both soluble and insoluble fiber affecting different properties of masa and tortillas. Besides the lack of fiber limits the potential health benefits for consumers. $\beta$-glucans are one alternative source of soluble fiber that can be added to maize flours to improve the physical, chemical, and sensory properties in masa and tortilla production as well as improving the health of consumers. Despite the potential benefits, little information exists on the addition of soluble fiber. Some reports have been shown the addition of nopal powder (Cornejo-Villegas et al., 2010) and dried cladodes of Opuntia ficus indica L. (Ramírez-Moreno et al., 2015) to nixtamalized maize flour with promising results. Nevertheless, there are not reports about the effect of addition of $\beta$-glucans as a source of soluble fiber on nixtamalized maize flours that described the properties such as WAC, texture, thermal and rheological of masa and tortillas and their relationship with the quality and consumer acceptability.

Moreover, since the tortillas have a short shelf life and an easy loss of freshness, so it takes just finding alternative conservation processes, combined with novel ingredients, as $\beta$-glucans to extend the shelf life of tortillas is attractive. A process as freezing can be an alternative to store tortillas and increase their availability of fresh tortillas, by subsequent thawing and cooking. However, it is important to study some properties of frozen products, such as thermal (fraction of frozen and unfrozen water, specific heat and enthalpy, among others), which have been used to determine the effect of freezing process and composition of food materials (Baier-Schenk et al., 2005; Matuda et al., 2005; Leray et al., 2010; Serventi et al., 2009; Curti et al., 2013). Therefore, the objective of this study was to supplement nixtamalized maize flours with $\beta$-glucans for making tortillas (frozen, thawed, and cooked) and evaluating their physicochemical, thermal, functional, and sensory characteristics.

\section{Materials and methods}

\subsection{Materials}

Two different commercial nixtamalized maize (Zea mays $L$.) flours and $\beta$-glucans extracted from barley with a purity of $26.5 \%$ (Barley Balance ${ }^{\mathrm{TM}}$, Canada) were used in this study.

\subsection{Experimental procedure}

Masas and tortillas preparation

Mixtures of two commercial nixtamalized maize flours $(3 \mathrm{~kg}$ of flour $\mathrm{A}$ and $3 \mathrm{~kg}$ of flour B) with $0 \%, 2 \%$, and $4 \%$ added $\beta$-glucans were prepared. For masa preparation, each lot was mixed with water (9 L) in an industrial mixer (Bathammex, model S-B2018, Mexico) for $3 \mathrm{~min}$, and adhesiveness, cohesiveness, color, moisture content, and WAC were determined. Pre-cooked tortillas (PTs) were then produced from the masas in a continuous band oven (Celorio, Mexico) at $250 \pm 10^{\circ} \mathrm{C}$ with a $30 \mathrm{~s}$ residence time, and moisture content and color were determined. PTs had a moisture content of 54-57\% and an average diameter and thickness of $12.5 \pm 0.1 \mathrm{~cm}$ and $1.0 \mathrm{~mm} \pm 0.01$, respectively. Then the PTs were air cooled to room temperature on a continuous band and subsequently packed in an individual vacuum chamber (Dajan, model DZ400-2D, China). The packages of each treatment were frozen and stored at $-18^{\circ} \mathrm{C}$ in a freezer (Torrey, model CHTC15, Mexico), until their analysis.

\section{Thawing and cooking the tortillas}

After one week of frozen storage, the tortillas were transferred to a refrigerator (Torrey, model R-25, Mexico) at $4{ }^{\circ} \mathrm{C}$ until thawed $(48 \mathrm{~h}$ ). Then, the thawed tortillas (TTs) were cooked on a hot griddle at $270 \pm 10^{\circ} \mathrm{C}$ for $20 \mathrm{~s}$ on each side, and then turned back to the first side and cooked until puffing. The cooked tortillas (CTs) for each treatment were covered in paper and stored in isolated thermal vessels for evaluation. The extensibility, rollability, color, and sensory evaluation of the tortillas were determined $30 \mathrm{~min}$ later at approximately $20^{\circ} \mathrm{C}$. Physicochemical characteristics of the tortillas with added $\beta$-glucans $(0 \%, 2 \%$, and $4 \%$ ) were compared to the control tortillas acquired from a retail tortilla store.

\subsection{Analytical methods}

\section{Proximate analysis}

The mixtures of nixtamalized flours and CTs enriched with $\beta$-glucans were analyzed for moisture, protein, fat, crude fiber, and ash contents according to methods $950.02,960.52,920.39$, 
962.09, and 923.03, respectively (Association of Official Analytical Chemists, 1998). Carbohydrates were calculated by difference.

\section{Insoluble and soluble fiber determination}

The insoluble and soluble fiber in the flours and CTs were determined with the total dietary fiber assay kit (Sigma-Aldrich, St. Louis, MO, USA) according to method 985.29 (Association of Official Analytical Chemists, 1997). The analysis was carried out in triplicate for each treatment, and the results were expressed in $\mathrm{g} / 100 \mathrm{~g}$.

\section{Moisture content determination for masa and tortillas}

The moisture content in masa and tortillas (PTs, TTs, and CTs) was determined using a gravimetric method 950.02 (Association of Official Analytical Chemists, 1998). The analysis was carried out in triplicate, and results were expressed in $\mathrm{g} / 100 \mathrm{~g}$.

\section{Water absorption capacity (WAC)}

The WAC of mixtures of nixtamalized flours with different concentrations of $\beta$-glucans was evaluated using the procedure described by Arámbula-Villa et al. (2001). Each mixture was tested three times. WAC was reported as grams ( $\mathrm{g}$ ) of water by $100 \mathrm{~g}$ of flour.

\subsection{Physical properties of masa and tortillas}

\section{Masa texture evaluation}

Adhesiveness and cohesiveness were evaluated according to the method described by Ruiz-Gutiérrez et al. (2012) through a texture profile analysis (TPA) using a TA.XT2 (Texture Analyser plus, UK) texturometer. Cubes of masa $(2 \times 2 \times 2 \mathrm{~cm})$ with a moisture content of $62-63.7 \%$ for each treatment were compressed $90 \%$ at a velocity of $300 \mathrm{~mm} / \mathrm{min}$ with a $5 \mathrm{~cm}$-diameter disc. The compression was repeated two seconds later. Ten replicates were performed from each treatment and an average value was reported.

\section{Tortilla texture analysis}

The maximum rollability force (MRF) and the maximum extensibility force (MEF) for tortillas with a moisture content of 42.3-46.5\% were performed using a TA.XT2 (Texture Analyser plus, UK) texturometer. The rollability was performed following the method used by Ruiz-Gutiérrez et al. (2012). A rollability accessory was used consisting of an acrylic platform with a rotary cylinder where the tortilla was rolled. The test was performed in tension mode at $3.0 \mathrm{~mm} / \mathrm{s}$ for a distance of $100 \mathrm{~mm}$. Fifteen tortillas were evaluated from each treatment and an average value was reported. The extensibility was determined according to the method described by Ruiz-Gutiérrez et al. (2012) using the HDP/TPB accessory in which the tortilla was placed between two rings and fixed with screws. Tortillas were compressed with a ball probe (diameter $=2.5 \mathrm{~cm}$ ) at $2 \mathrm{~mm} / \mathrm{s}$ for a distance of $25 \mathrm{~mm}$. Fifteen tortillas were evaluated from each treatment and an average value was reported.

\section{Color measurements for masa and tortillas}

Color measurements for masa and tortillas were determined with a Konica Minolta CR-400/410 (Minolta Co., Osaka, Japan), following the method described by Sánchez-Madrigal et al. (2014). The $\mathrm{L}^{*}, \mathrm{a}^{*}, \mathrm{~b}^{*}$ and $\Delta E$ parameters were determined through five measurements in five tortillas and ten measurements in masa for each treatment.

\section{Differential scanning calorimetry (DSC)}

The ice melting peak (enthalpy) of frozen tortillas was measured by DSC according to the methods of Vittadini et al. (2004) and Clubbs et al. (2008) with some modifications. Frozen tortilla $(\approx 15 \mathrm{mg})$ was placed into a hermetically sealed aluminum pan and analyzed with a TA Instruments calorimeter (Q-200, Crawley, UK) with a program of $-40^{\circ} \mathrm{C}$ to $100^{\circ} \mathrm{C}$ at $5{ }^{\circ} \mathrm{C} / \mathrm{min}$. An empty pan was used as a reference. DSC thermograms were analyzed with Universal Analysis software (TA Instruments, Crawley, UK), and the peak enthalpy for each sample was obtained. Frozen water (FW) in tortillas was obtained from the endothermic melting peak around $0{ }^{\circ} \mathrm{C}$ corresponding to ice melting. The enthalpy of this transition was used to calculate FW using the following Equation 1:

$$
\begin{aligned}
& \% \mathrm{FW}=\text { peak enthalpy } \times\left(\frac{1}{\text { latent heat of fusion of ice }}\right) \times \\
& \left(\frac{1}{\mathrm{~g} \text { total water } / \mathrm{g} \text { sample }}\right) \times 100
\end{aligned}
$$

Where the latent heat of fusion of ice is $334 \mathrm{~J} / \mathrm{g}$ (Vittadini et al., 2004). The analysis was performed in triplicate, and an average value was reported.

\section{Confocal laser scanning microscopy (CLSM)}

Tortilla samples before dehydrated at $45^{\circ} \mathrm{C}$ and then ground, were stained with two fluorescent dyes to identify the starch and $\beta$-glucan components. Fluorescein (sodium salt, $0.05 \%$ of flour weight, Sigma Chemicals, St. Louis, MO, USA) was used to stain the starch components (green in images) and calcofluor white (Sigma Chemicals, St. Louis, MO, USA) was used to identify $\beta$-glucans (blue in images). The stained samples were loaded on object glasses and analyzed under confocal laser scanning microscopy (Zeiss, model LSM 700, Heidelberg, Germany). The light emitted from the fluorescein and calcofluor white dyes was detected for the excitation wavelengths of $488 \mathrm{~nm}$ and $405 \mathrm{~nm}$, respectively.

\subsection{Sensory analysis of tortillas}

Differences between the acceptability of the tortillas were determined by a discriminative and affective sensory analysis using a triangle test. The test was conducted using twenty-eight untrained judges according to Stone et al. (2012).

\subsection{Statistical analyses}

The data obtained for treatments at different percentages of $\beta$-glucans were subjected to a variance analysis (ANOVA) using Minitab version 16 software (Minitab, 2010, PA, USA). 
Differences between means of treatments were compared by Tukey's test at $\mathrm{P}<0.05$, and masa and tortillas acquired from a retail tortilla store were used as the control. The results obtained in the sensory analysis were analyzed using a triangle-test significance table $(\mathrm{P}<0.05)$.

\section{Results and discussion}

\subsection{Proximate analysis}

Table 1 shows the proximate analysis of flours (0\%), and enriched with $\beta$-glucans ( $2 \%$ and $4 \%$ ). The fat, protein, and carbohydrate content of all flours did not show significant differences $(P>0.05)$ between them. However, the ash and crude fiber content between flours and tortillas with $0 \%$ and $4 \% \beta$-glucans were significantly different $(\mathrm{P}<0.05)$. Regarding the fiber dietary content, insoluble fiber increased in both flours and tortillas as $\beta$-glucan concentration increased, but not significant difference was found between them. This slight increase of insoluble fiber in both flours and tortillas could be attributed to the insoluble fraction of $\beta$-glucans. $\beta$-glucans are divided into soluble and insoluble depending on the number of $\beta-(1-3)$ linkages present and the degree of polymerization, and an increase in the number of $\beta$-(1-3) linkages in the $\beta$-glucans, results in a larger proportion of soluble fiber (Zhao et al., 2014).

Therefore, the soluble fiber content of flours and tortillas was significantly increased $(\mathrm{P}<0.05)$ by increasing the concentration of $\beta$-glucans (Table 1). This increase was over threefold in tortillas with $2 \%$ and over fivefold in tortillas with $4 \% \beta$-glucans compared to tortillas without $\beta$-glucans $(0 \%)$. This effect was correlated by microscopy analysis (Figure 1 ), where the blue structures ( $\beta$-glucans according to dye used) were increased as $\beta$-glucan concentration was increased in the flours. Increases in dietary fiber have been reported in tortillas from nixtamalized maize flours with added flaxseed flours (Rendón-Villalobos et al., 2009). Similar findings reported increases in soluble and insoluble fiber in instant maize flours with added nopal powder (Cornejo-Villegas et al., 2010) and dried cladodes (Ramírez-Moreno et al., 2015).

\subsection{Water absorption capacity and moisture content of masa and tortillas}

The WAC and moisture content of masa and tortillas enriched with $\beta$-glucans are shown in Table 2.

These results show the moisture content in masa and tortillas (PTs, TTs, and CTs) decreased significantly as $\beta$-glucans increased, except for TTs. This significant difference $(\mathrm{P}<0.05)$ was observed in masas and CTs with $2 \%$ and $4 \%$ added $\beta$-glucans in comparison with masa and CTs without $\beta$-glucans ( $0 \%)$. The WAC values showed significant differences at all concentrations $(\mathrm{P}<0.05)$, and increased as $\beta$-glucan concentration increased. This result, together with the decrease in moisture content as $\beta$-glucans increased can be attributed to the ability of these components to absorb or bind water (Lazaridou \& Biliaderis, 2007; Foschia et al., 2013; Kurek et al., 2015).

\subsection{Color of masa and tortillas}

The color values for masa and tortillas enriched with $\beta$-glucans are shown in Table 3. The luminosity, represented by the $L^{*}$ parameter, of masas and tortillas decreased significantly $(\mathrm{P}<0.05)$ with increasing $\beta$-glucan concentration, except for TTs. The parameter $\mathrm{a}^{*}$, represents greenness (-) and redness $(+)$ tendencies. Masa and tortillas with added $\beta$-glucans had increased $\mathrm{a}^{*}$ parameter values (trended to redness) compared to the controls with significant differences at all concentrations

Table 1. Proximate composition and dietary fiber ${ }^{\star}$ of flours and tortillas enriched with $\beta$-glucans.

\begin{tabular}{|c|c|c|c|c|c|c|}
\hline \multirow{2}{*}{ Component } & \multicolumn{3}{|c|}{ Flours } & \multicolumn{3}{|c|}{ Tortillas } \\
\hline & $0 \%$ & $2 \%$ & $4 \%$ & $0 \%$ & $2 \%$ & $4 \%$ \\
\hline Fat & $4.75 \pm 0.09^{a}$ & $4.78 \pm 0.05^{\mathrm{a}}$ & $4.55 \pm 0.10^{\mathrm{a}}$ & $1.91 \pm 0.06^{\mathrm{a}}$ & $1.69 \pm 0.27^{\mathrm{a}}$ & $1.51 \pm 0.15^{\mathrm{a}}$ \\
\hline Protein & $9.10 \pm 0.19^{\mathrm{a}}$ & $9.22 \pm 0.40^{\mathrm{a}}$ & $9.29 \pm 0.23^{\mathrm{a}}$ & $8.98 \pm 0.04^{\mathrm{a}}$ & $9.00 \pm 0.09^{a}$ & $9.01 \pm 0.06^{\mathrm{a}}$ \\
\hline Ash & $1.39 \pm 0.01^{b}$ & $1.40 \pm 0.01^{\mathrm{b}}$ & $1.46 \pm 0.06^{\mathrm{ab}}$ & $1.36 \pm 0.01^{b}$ & $1.38 \pm 0.01^{\mathrm{ab}}$ & $1.41 \pm 0.02^{\mathrm{a}}$ \\
\hline Crude fiber & $1.69 \pm 0.03^{c}$ & $1.74 \pm 0.02^{\mathrm{cb}}$ & $1.77 \pm 0.01^{\mathrm{b}}$ & $2.55 \pm 0.02^{b}$ & $2.60 \pm 0.01^{\mathrm{ab}}$ & $2.66 \pm 0.03^{\mathrm{a}}$ \\
\hline Carbohydrates & $83.07 \pm 0.21^{\mathrm{a}}$ & $82.86 \pm 0.73 a$ & $82.95 \pm 0.62^{\mathrm{a}}$ & $85.20 \pm 0.01^{\mathrm{a}}$ & $85.33 \pm 0.42^{\mathrm{a}}$ & $85.41 \pm 0.23^{\mathrm{a}}$ \\
\hline Insoluble fiber & $8.42 \pm 0.43^{\mathrm{b}}$ & $8.68 \pm 0.37^{\mathrm{ab}}$ & $9.00 \pm 0.45^{\mathrm{ab}}$ & $12.43 \pm 0.53^{\mathrm{a}}$ & $12.53 \pm 0.51^{\mathrm{a}}$ & $12.84 \pm 0.36^{\mathrm{a}}$ \\
\hline Soluble fiber & $0.25 \pm 0.07^{c}$ & $0.76 \pm 0.08^{\mathrm{b}}$ & $1.27 \pm 0.08^{\mathrm{a}}$ & $0.28 \pm 0.06^{c}$ & $0.88 \pm 0.09^{b}$ & $1.47 \pm 0.11^{\mathrm{a}}$ \\
\hline
\end{tabular}

Table 2. Water absorption capacity and moisture content in masa and tortillas* enriched with $\beta$-glucans.

\begin{tabular}{|c|c|c|c|c|c|}
\hline $\begin{array}{c}\beta \text {-glucans } \\
\text { concentration }\end{array}$ & $\begin{array}{c}\text { WAC } \\
(\mathrm{g} / 100 \mathrm{~g})\end{array}$ & $\begin{array}{c}\text { Masa } \\
(\%)\end{array}$ & $\begin{array}{l}\text { PTs } \\
(\%)\end{array}$ & $\begin{array}{l}\text { TTs } \\
(\%)\end{array}$ & $\begin{array}{l}\text { CTs } \\
(\%)\end{array}$ \\
\hline $0 \%$ & $148.60 \pm 0.18^{c}$ & $63.68 \pm 0.29^{b}$ & $56.99 \pm 0.18^{\mathrm{a}}$ & $57.23 \pm 0.21^{\mathrm{a}}$ & $46.49 \pm 0.87^{b}$ \\
\hline $2 \%$ & $150.50 \pm 0.30^{\mathrm{b}}$ & $62.40 \pm 0.21^{\mathrm{c}}$ & $55.46 \pm 0.01^{\mathrm{b}}$ & $55.76 \pm 0.99^{\mathrm{a}}$ & $42.61 \pm 0.09^{c}$ \\
\hline $4 \%$ & $152.20 \pm 0.35^{\mathrm{a}}$ & $62.01 \pm 0.02^{c}$ & $54.24 \pm 0.19^{c}$ & $54.77 \pm 0.45^{\mathrm{a}}$ & $42.32 \pm 0.49^{\circ}$ \\
\hline Control & ND & $64.96 \pm 0.01^{\mathrm{a}}$ & ND & ND & $54.56 \pm 0.15^{\mathrm{a}}$ \\
\hline
\end{tabular}

${ }^{\star}$ Mean values \pm standard error. Means by column with different letters show significant difference, Tukey's test $(\mathrm{P}<0.05)$. WAC, water absorption capacity; PTs, precooked tortillas;

TTs, thawed tortillas; CTs, cooked tortillas; ND, not determined. 
Table 3. Results of color ${ }^{\star}$ in masa and tortillas enriched with $\beta$-glucans.

\begin{tabular}{|c|c|c|c|c|c|}
\hline & $\beta$-glucans concentration & $\mathrm{L}^{*}$ & $\mathrm{a}^{*}$ & $\mathrm{~b}^{*}$ & $\Delta \mathrm{E}$ \\
\hline \multirow{4}{*}{ Masa } & $0 \%$ & $82.54 \pm 0.28^{\mathrm{b}}$ & $-1.42 \pm 0.01^{\mathrm{b}}$ & $17.88 \pm 0.10^{\mathrm{a}}$ & $22.56 \pm 0.07^{b}$ \\
\hline & $2 \%$ & $80.80 \pm 0.14^{\mathrm{b}}$ & $-0.95 \pm 0.01^{\mathrm{ab}}$ & $17.44 \pm 0.08^{\mathrm{a}}$ & $23.59 \pm 0.16^{\mathrm{ab}}$ \\
\hline & $4 \%$ & $79.73 \pm 0.02^{c}$ & $-0.61 \pm 0.01^{\mathrm{a}}$ & $17.36 \pm 0.16^{\mathrm{a}}$ & $24.05 \pm 0.14^{\mathrm{a}}$ \\
\hline & Control & $84.80 \pm 0.67^{\mathrm{a}}$ & $-2.35 \pm 0.16^{c}$ & $15.96 \pm 0.35^{\mathrm{b}}$ & $20.87 \pm 0.27^{c}$ \\
\hline \multirow{3}{*}{ PTs } & $0 \%$ & $79.54 \pm 0.11^{\mathrm{a}}$ & $-0.94 \pm 0.02^{c}$ & $19.08 \pm 0.14^{\mathrm{a}}$ & $25.63 \pm 0.01^{b}$ \\
\hline & $2 \%$ & $76.04 \pm 0.67^{\mathrm{b}}$ & $-0.36 \pm 0.01^{\mathrm{b}}$ & $19.35 \pm 0.01^{\mathrm{a}}$ & $28.42 \pm 0.52^{\mathrm{a}}$ \\
\hline & $4 \%$ & $73.84 \pm 0.28^{c}$ & $0.32 \pm 0.05^{\mathrm{a}}$ & $18.46 \pm 0.02^{\mathrm{b}}$ & $29.62 \pm 0.22^{\mathrm{a}}$ \\
\hline \multirow{3}{*}{ FTs } & $0 \%$ & $75.27 \pm 0.76^{\mathrm{a}}$ & $-2.47 \pm 0.04^{\mathrm{b}}$ & $18.53 \pm 0.03^{\mathrm{a}}$ & $28.61 \pm 0.58^{\mathrm{a}}$ \\
\hline & $2 \%$ & $75.03 \pm 0.04^{\mathrm{a}}$ & $-2.03 \pm 0.17^{\mathrm{ab}}$ & $17.51 \pm 0.40^{\mathrm{b}}$ & $28.18 \pm 0.25^{\mathrm{a}}$ \\
\hline & $4 \%$ & $73.66 \pm 0.42^{\mathrm{a}}$ & $-1.43 \pm 0.19^{\mathrm{a}}$ & $17.33 \pm 0.06^{\mathrm{b}}$ & $29.16 \pm 0.39^{\mathrm{a}}$ \\
\hline \multirow{4}{*}{ CTs } & $0 \%$ & $74.58 \pm 0.04^{\mathrm{ab}}$ & $-1.81 \pm 0.01^{\mathrm{c}}$ & $20.56 \pm 0.18^{\mathrm{a}}$ & $30.36 \pm 0.07^{b}$ \\
\hline & $2 \%$ & $71.94 \pm 0.24^{\mathrm{bc}}$ & $-1.23 \pm 0.01^{\mathrm{b}}$ & $20.72 \pm 0.34^{\mathrm{a}}$ & $32.51 \pm 0.01^{\mathrm{ab}}$ \\
\hline & $4 \%$ & $70.15 \pm 0.09^{c}$ & $-0.40 \pm 0.08^{\mathrm{a}}$ & $20.78 \pm 0.02^{\mathrm{a}}$ & $34.35 \pm 0.61^{\mathrm{a}}$ \\
\hline & Control & $76.94 \pm 0.69^{\mathrm{a}}$ & $-2.42 \pm 0.10^{\mathrm{d}}$ & $15.77 \pm 0.35^{\mathrm{c}}$ & $25.66 \pm 0.64^{\mathrm{c}}$ \\
\hline
\end{tabular}

${ }^{*}$ Mean values \pm stardad error. Means by column with different letters show significant difference, Tukey's test $(\mathrm{P}<0.05)$. PTs, precooked tortillas; TTs, thawed tortillas; CTs, cooked tortillas.
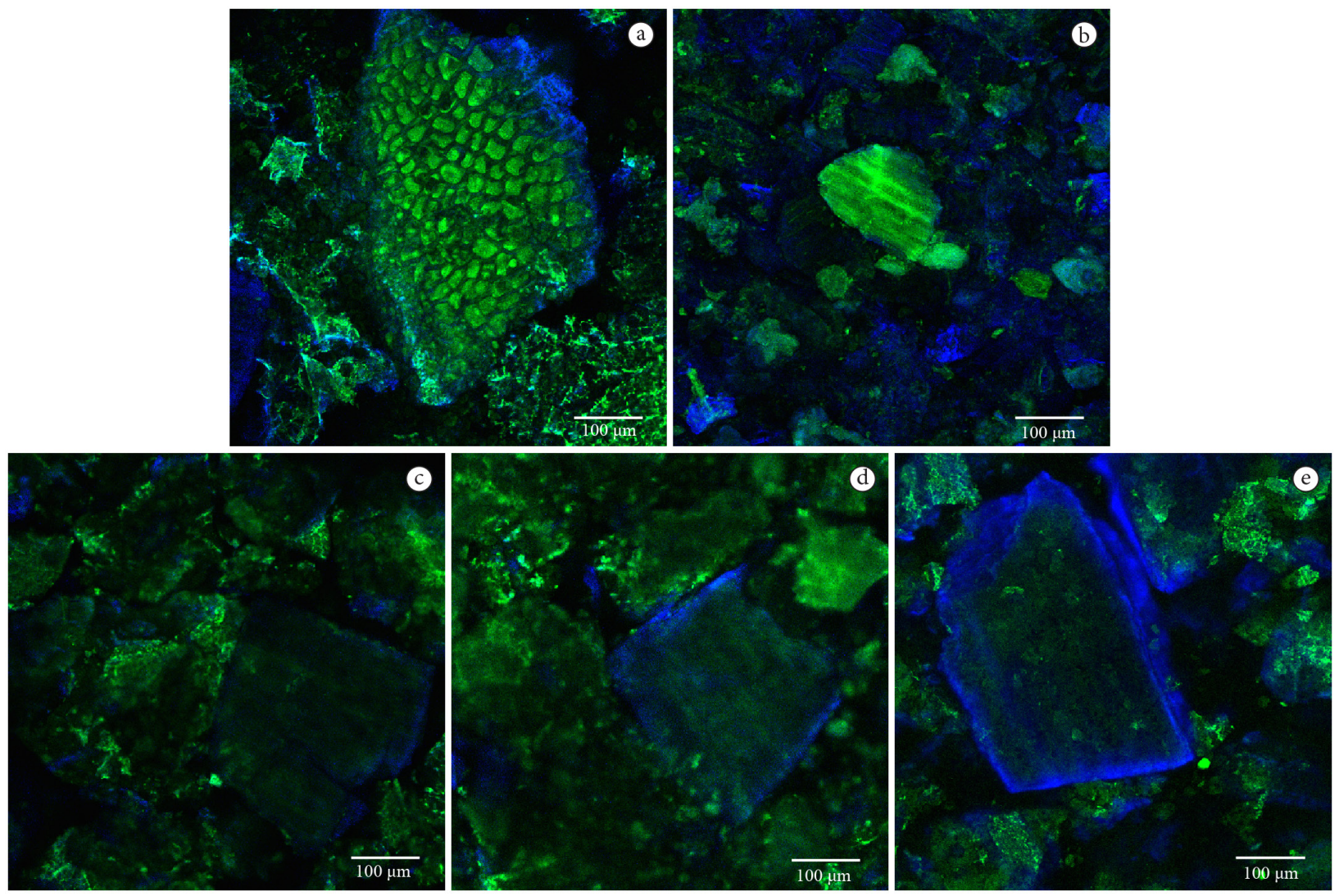

Figure 1. Micrographs of tortillas enriched with $\beta$-glucans. (a) nixtamalized maize flour, (b) $\beta$-glucans, (c) tortilla without $\beta$-glucans, (d) tortilla with $2 \% \beta$-glucans, (e) tortilla with $4 \% \beta$-glucans.

except for TTs, which showed differences between $0 \%$ and $4 \%$ $\beta$-glucans.

Decreasing $L^{*}$ parameter values for masas and tortillas indicate that they became darker, which could be the effect of $\beta$-glucans presence imparting dark colors. This effect was confirmed with the $\mathrm{L}^{*}$ parameter of tortillas control, which did not show a significant difference to tortillas without $\beta$-glucans
(Table 3). This decreasing of $\mathrm{L}^{\star}$ values also has been reported by Kurek et al. (2015) in wheat bread added with $\beta$-glucans. The parameter $b^{*}$, represents blueness $(-)$ and yellowness $(+)$ tendencies, was significantly affected $(\mathrm{P}<0.05)$ by the highest concentration of $\beta$-glucans in PTs and TTs. The $b^{*}$ parameter value of CTs was higher than masa and other tortillas, indicating yellowness tonalities. These changes are a result of Maillard and caramelization reactions during high temperature cooking 
(Ruiz-Gutiérrez et al., 2012) and cause decrease in $\mathrm{L}^{\star}$ parameter values (Table 3$)$. The total color difference $(\Delta \mathrm{E})$ of masa and tortillas was different $(\mathrm{P}<0.05)$ for $0 \%$ and $4 \% \beta$-glucans, indicating that higher than $2 \% \beta$-glucans cause color differences. No differences were observed in TTs for any concentration of $\beta$-glucans, indicating that the freezing process did not affect the color. However, the control was different for both masa and tortillas at all treatments.

\subsection{Texture of masa and tortillas}

The texture of masa and tortillas enriched with $\beta$-glucans is shown in Table 4 . The adhesiveness and cohesiveness increased as the concentration of $\beta$-glucans increased. Significant differences in the adhesiveness between masa without $\beta$-glucans and with $2 \%$ and $4 \% \beta$-glucans were observed, although a significant effect between them and the masa control was not found. For cohesiveness, significant differences among $0 \%$ and $4 \% \beta$-glucans were observed.

The highest adhesiveness $(-4.12 \mathrm{~N})$ and cohesiveness $(0.25)$ was obtained for masa with $4 \% \beta$-glucans. Increases in the adhesiveness and cohesiveness values are associated with viscosity properties produced by the $\beta$-glucans as previously reported by Limberger-Bayer et al. (2014) and Zhu et al. (2016). The textural characteristics such as adhesiveness and cohesiveness of masa are important (Valderrama-Bravo et al., 2015) since low adhesiveness values can generate problems during the tortilla modeling stage of the industrial manufacturing process. Adhesiveness values found for $2 \%$ and $4 \% \beta$-glucans were similar to those reported by Ruiz-Gutiérrez et al. (2012) in nixtamalized masa with $\mathrm{Ca}(\mathrm{OH})_{2}$. In addition, the reported adhesiveness and cohesiveness values for commercial masa are identical to the values obtained in this study for masa without $\beta$-glucans ( $0 \%)$. The texture of masa control did not show differences with masas of all treatments. The extensibility and rollability of tortillas are shown in Table 4. The MEF and MRF of tortillas did not show significant differences $(\mathrm{P}<0.05)$ at any $\beta$-glucan concentration or with the control. The extensibility and rollability of tortillas were lower than those reported by Osorio-Díaz et al. (2011), and Ruiz-Gutiérrez et al. (2012). This suggests that the process of freezing and thawing decreases the rollability values of tortillas. The rollability values of the tortilla control were higher or similar to other reports; however, in this research the tortilla control did not show a significant difference among tortillas enriched with $\beta$-glucans (Table 4). Ramírez-Moreno et al. (2015) did not reported changes in the rollability of tortillas with and without fiber of dried cladodes.

\subsection{Differential Scanning Calorimetry (DSC)}

On frozen materials, the most common thermal analysis measurement is the determination of frozen and unfrozen water, which is obtained by integrating the ice/water melting peak and comparing this value with the known moisture content (MacNaughtan \& Farhat, 2008). Therefore, from DSC analysis, properties of water at a structural level were obtained and the enthalpy of ice melting of FTs and the corresponding amount of FW were determined and presented in Table 5.

The enthalpy of ice melting and the FW increased significantly as $\beta$-glucan concentration increased showing differences $(P<0.05)$ between each $\beta$-glucan concentration in FTs. The melting enthalpies and FW found in this study were higher than those reported by Vittadini et al. (2004) and Clubbs et al. (2008) in maize tortillas added with glycerol and by Baier-Schenk et al. (2005), Leray et al. (2010), Matuda et al. (2011) and Chen et al. (2012) in frozen wheat doughs. This increase of FW was reported by Serventi et al. (2009) for frozen wheat tortillas enriched with whole kamut ${ }^{\circledR}$ flour and by Curti et al. (2013) for frozen wheat bread enriched with bran. Both studies attributed this effect to a weak water-solid interaction induced by fiber present in kamut ${ }^{\circledR}$ or bran, respectively. The increase of FW found throughout of this study possibly occurs by the same effect, a weak interaction of $\beta$-glucans with water present in FTs. This weaker interaction of $\beta$-glucans with water may have been the cause of decreasing of bound water in the system, since according to Chaplin (2003) the unfreezable water is more tightly and specifically bound. Therefore the unfreezable water also decreased, resulting in an increasing of FW in FTs.

\subsection{Sensory analysis}

The sensory analysis determined by twenty-eight consumer judges showed through a triangle test that only tortillas without $\beta$-glucans $(0 \%)$ and $4 \% \beta$-glucans were significantly different (Table 6).

This difference was detected by $71.4 \%$ of the judges. The main characteristic differences between tortillas (Figure 2) according to judges were flavor (0.96), texture (0.75), odor (0.64), and color (0.21). Although the tortillas color was statistically different $(\mathrm{P}<0.05)$ in $0 \%$ and $4 \% \beta$-glucan concentrations (Table 3 ) by instrumental determination, this characteristic was the least mentioned by the judges. In contrast, the textural characteristics were mentioned more often; however, these were not significantly different $(\mathrm{P}<0.05)$ in the instrumental measurement. Tortilla

Table 4. Results of texture* in masa and tortillas enriched with $\beta$-glucans.

\begin{tabular}{|c|c|c|c|c|}
\hline \multirow[b]{2}{*}{$\beta$-glucans concentration } & \multicolumn{2}{|c|}{ TPA } & \multirow{2}{*}{$\begin{array}{c}\text { Extensibility } \\
\text { MEF } \\
(\mathrm{N})\end{array}$} & \multirow{2}{*}{$\begin{array}{c}\text { Rollability } \\
\text { MRF } \\
(\mathrm{N})\end{array}$} \\
\hline & $\begin{array}{c}\text { Adhesiveness } \\
(\mathrm{N})\end{array}$ & Cohesiveness & & \\
\hline $0 \%$ & $-3.26 \pm 0.02^{\mathrm{a}}$ & $0.18 \pm 0.01^{b}$ & $3.39 \pm 0.67^{\mathrm{a}}$ & $0.18 \pm 0.01^{\mathrm{a}}$ \\
\hline $2 \%$ & $-3.88 \pm 0.01^{b}$ & $0.22 \pm 0.01^{\mathrm{ab}}$ & $2.87 \pm 0.30^{\mathrm{a}}$ & $0.17 \pm 0.01^{\mathrm{a}}$ \\
\hline $4 \%$ & $-4.12 \pm 0.16^{b}$ & $0.25 \pm 0.01^{\mathrm{a}}$ & $2.61 \pm 0.01^{\mathrm{a}}$ & $0.15 \pm 0.01^{\mathrm{a}}$ \\
\hline Control & $-3.23 \pm 0.43^{\mathrm{ab}}$ & $0.19 \pm 0.01^{\mathrm{ab}}$ & $3.33 \pm 0.41^{\mathrm{a}}$ & $0.20 \pm 0.02^{\mathrm{a}}$ \\
\hline
\end{tabular}

${ }^{\star}$ Mean values \pm stardard error. Means by column with different letters show significant difference, Tukey's test $(\mathrm{P}<0.05)$. TPA, texture profile analysis; MEF, maximum extensibility force; MRF, maximum rollability force. 
Table 5. Enthalpy values* of ice melting and amount of frozen water in tortillas.

\begin{tabular}{ccc}
\hline $\begin{array}{c}\beta \text {-glucans } \\
\text { concentration }\end{array}$ & $\begin{array}{c}\text { Enthalpy } \\
(\mathrm{J} / \mathrm{g})\end{array}$ & $\begin{array}{c}\text { FW } \\
(\mathrm{g} \text { FW/100 g water })\end{array}$ \\
\hline $0 \%$ & $131.02 \pm 0.88^{\mathrm{c}}$ & $71.72 \pm 0.46^{\mathrm{c}}$ \\
$2 \%$ & $135.80 \pm 2.87^{\mathrm{b}}$ & $75.85 \pm 1.60^{\mathrm{b}}$ \\
$4 \%$ & $140.85 \pm 0.96^{\mathrm{a}}$ & $77.41 \pm 0.66^{\mathrm{a}}$ \\
\hline
\end{tabular}

${ }^{\star}$ Mean values \pm standard error. Means by column with different letters show significant difference, Tukey's test $(\mathrm{P}<0.05)$. FW, frozen water.

Table 6. Difference between sensory comparisons for tortillas enriched with $\beta$-glucans.

\begin{tabular}{ccccc}
\hline $\begin{array}{c}\text { Tortilla } \\
\text { comparisons }\end{array}$ & $\begin{array}{c}\text { Consumers: } \\
\text { Difference } \\
\text { found }\end{array}$ & $\begin{array}{c}\text { Consumers: } \\
\text { No difference } \\
\text { found }\end{array}$ & $\begin{array}{c}\text { Consumers: } \\
\text { Total }\end{array}$ & $\mathrm{P}^{*}$ \\
\hline $0 \%-2 \%$ & 13 & 15 & 28 & $>0.05$ \\
$0 \%-4 \%$ & 20 & 8 & 28 & $<0.001$ \\
$2 \%-4 \%$ & 8 & 20 & 28 & $>0.05$ \\
\hline
\end{tabular}

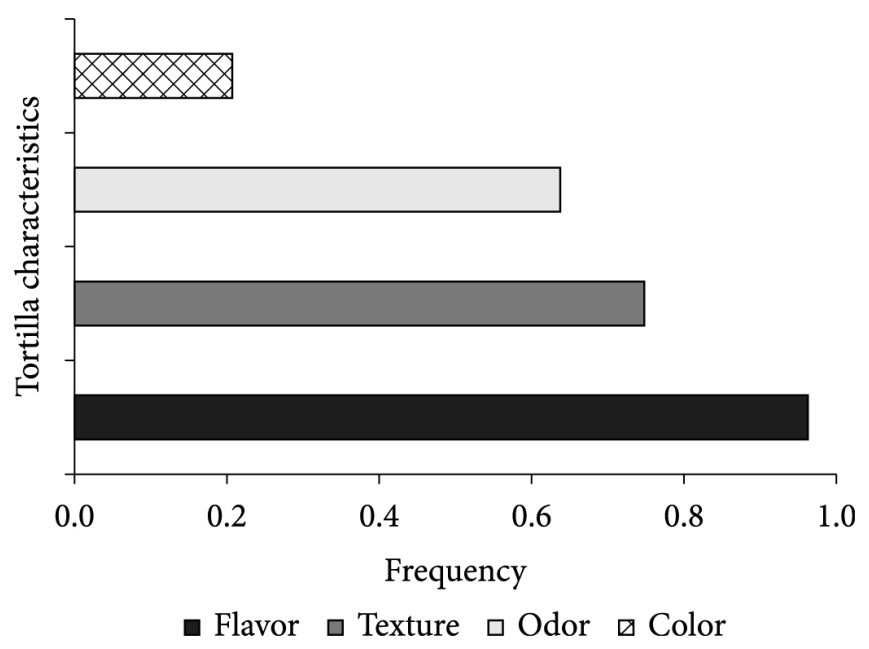

Figure 2. Characteristic frequency described by the judges in the differences of tortillas enriched with $\beta$-glucans.

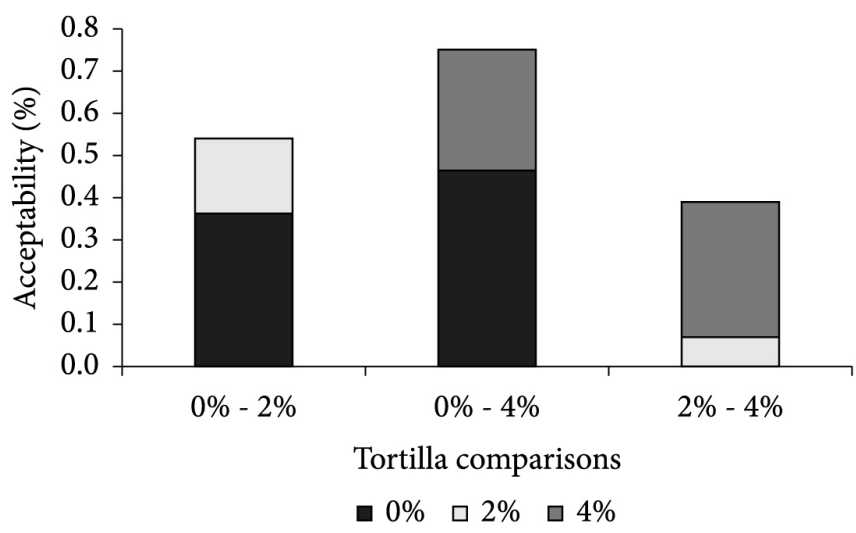

Figure 3. Comparisons between tortillas enriched with $\beta$-glucans using the triangle test. acceptability was evaluated through an affective test comparing the tortillas with different $\beta$-glucan concentrations (Figure 3 ).

All comparisons between tortillas showed significant differences $(\mathrm{P}<0.05)$. The tortillas without $\beta$-glucans $(0 \%)$ had a higher acceptance, and no differences were found for tortillas with $2 \% \beta$-glucans. However, judges detected differences between tortillas with $0 \%$ and $4 \% \beta$-glucans (Table 6 ), and the last tortillas (4\%) were more accepted by judges than tortillas with $2 \% \beta$-glucans (Figure 3 ). The sensory score showed that $36 \%$ of judges mentioned that tortillas with $2 \%$ and $4 \% \beta$-glucans had better flavor.

\section{Conclusions}

$\beta$-glucans increased the dietary fiber content, particularly soluble fiber content by over threefold in tortillas with $2 \%$ and over fivefold in tortillas with $4 \%$. The moisture content of masa and tortillas decreased as $\beta$-glucan concentration was increased; however, the WAC increased. Only added concentrations of $0 \%$ and $4 \% \beta$-glucans were different in the color of masa, PTs, and CTs as well as adhesiveness and cohesiveness of masa were different for $0 \%$ and $4 \%$ added $\beta$-glucans. $\beta$-glucan addition did not affect the texture of tortillas. The ice melting enthalpy and FW were increased with added $\beta$-glucans in FTs. The microscopy analysis showed a major presence of polysaccharide as $\beta$-glucan concentration was increased. This was related to soluble fiber content, WAC, masa texture, and tortillas as well as thermal properties of tortillas. Tortillas with $2 \% \beta$-glucans showed acceptable properties compared to commercial tortillas, but with over triple the amount of soluble fiber. These results suggest that frozen tortillas with fiber added may increase their shelf life while maintaining good physicochemical, functional, and sensory properties after cooking.

\section{Acknowledgements}

The authors acknowledge the Universidad Autónoma de Chihuahua and the Consejo Nacional de Ciencia y Tecnología (National Council of Science and Technology) for their support in the realization of the Technological and Innovation Project (Project No. 198065 - CONACYT).

\section{References}

Arámbula-Villa, G., González-Hernández, J., \& Ordorica-Falomir, C. A. (2001). Physicochemical, structural and textural properties of tortillas form extruded instant corn flour supplemented with various types of corn lipids. Journal of Cereal Science, 33(1), 245-252. http:// dx.doi.org/10.1006/jcrs.2001.0372.

Association of Official Analytical Chemists - AOAC. (1997). Method 960.52: Official Methods of Analysis of Association of Official Analytical Chemists (Vol. 1, 16th ed., Section 12.1.07). Washington: AOAC International.

Association of Official Analytical Chemists - AOAC. (1998). Official Methods of Analysis of Association of Official Analytical Chemists (15th ed.). Washington: AOAC International.

Baier-Schenk, A., Handschin, S., \& Conde-Petit, B. (2005). Ice in prefermented frozen bread dough-an investigation based on 
calorimetry and microscopy. Cereal Chemistry, 82(3), 251-255. http://dx.doi.org/10.1094/CC-82-0251.

Barrón, J. M., \& Espinoza, A. (1993). Fortification of maize tortilla with alkali-treated chickpea flour. International Journal of Food Science \& Technology, 28(5), 505-511. http://dx.doi.org/10.1111/j.1365-2621.1993. tb01299.x.

Bressani, R., Turcios, J. C., Reyes, L., \& Mérida, R. (2001). Caracterización física y química de harinas industriales nixtamalizadas de maíz de consumo humano en América Central. Archivos Latinoamericanos de Nutricion, 51(3), 309-313. PMid:11791485.

Chaplin, M. F. (2003). Fibre and water binding. The Proceedings of the Nutrition Society, 62(1), 223-227. http://dx.doi.org/10.1079/ PNS2002203. PMid:12756971.

Chen, G., Jansson, H., Lustrup, K. F., \& Swenson, J. (2012). Formation and distribution of ice upon freezing of different formulations of wheat bread. Journal of Cereal Science, 55(3), 279-284. http://dx.doi. org/10.1016/j.jcs.2011.12.008.

Clubbs, E. A., Vittadini, E., Shellhammer, T. H., \& Vodovotz, Y. (2008). Effects of storage on the physico-chemical properties of corn tortillas prepared with glycerol and salt. Journal of Cereal Science, 47(2), 162-17. http://dx.doi.org/10.1016/j.jcs.2007.03.007.

Cornejo-Villegas, M. A., Acosta-Osorio, A. A., Rojas-Molina, I., Gutiérrez-Cortéz, E., Quiroga, M. A., Gaytán, M., Herrera, G., \& Rodríguez-García, M. E. (2010). Study of the physicochemical and pasting properties of instant corn flour added with calcium and fibers from nopal powder. Journal of Food Engineering, 96(3), 401409. http://dx.doi.org/10.1016/j.jfoodeng.2009.08.014.

Curti, E., Carini, E., Bonacini, G., Tribuzio, G., \& Vittadini, E. (2013). Effect of the addition of bran fractions on bread properties. Journal of Cereal Science, 57(3), 325-332. http://dx.doi.org/10.1016/j. jcs.2012.12.003.

Foschia, M., Peressini, D., Sensidoni, A., \& Brennan, C. S. (2013). The effects of dietary fibre addition on the quality of common cereal products. Journal of Cereal Science, 58(2), 216-227. http://dx.doi. org/10.1016/j.jcs.2013.05.010.

Gutiérrez, E., Rojas-Molina, I., Pons-Hernández, J. L., Guzmán, H., Aguas-Angel, B., Arenas, J., Fernández, P., Palacios-Fonseca, A., Herrera, G., \& Rodríguez, M. E. (2007). Study of calcium ion diffusion in nixtamalized quality protein maize as a function of the cooking temperature. Cereal Chemistry, 84(2), 186-194. http:// dx.doi.org/10.1094/CCHEM-84-2-0186.

Ishida, P. M. G., \& Steel, C. J. (2014). Physicochemical and sensory characteristics of pan bread samples available in the Brazilian market. Food Science and Technology, 34(4), 746-754. http://dx.doi. org/10.1590/1678-457X.6453.

Khoury, D. E., Cuda, C., Luhovyy, B. L., \& Anderson G. H. (2012). Beta glucan: health benefits in obesity and metabolic syndrome. Journal of Nutrition and Metabolism, 2012(1), 1-28. http://dx.doi. org/10.1155/2012/851362.

Kurek, M. A., Wyrwisz, J., Piwińska, M., \& Wierzbicka, A. (2015). Influence of the wheat flour extraction degree in the quality of bread made with high proportions of $\beta$-glucan. Food Science and Technology, 35(2), 273-278. http://dx.doi.org/10.1590/1678-457X.6537.

Lazaridou, A., \& Biliaderis, C. G. (2007). Molecular aspects of cereal $\beta$-glucan functionality: Physical properties, technological applications and physiological effects. Journal of Cereal Science, 46(2), 101-118. http://dx.doi.org/10.1016/j.jcs.2007.05.003.

Leray, G., Oliete, B., Mezaize, S., Chevallier, S., \& De Lamballeriem, M. (2010). Effects of freezing and frozen storage conditions on the rheological properties of different formulations of non-yeasted wheat and gluten-free bread dough. Journal of Food Engineering, 100(1), 70-76. http://dx.doi.org/10.1016/j.jfoodeng.2010.03.029.

Limberger-Bayer, V. M., de Francisco, A., Chan, A., Oro, T., Ogliari, P. J., \& Barreto, P. L. M. (2014). Barley $\beta$-glucans extraction and partial characterization. Food Chemistry, 154(1), 84-89. http://dx.doi. org/10.1016/j.foodchem.2013.12.104. PMid:24518319.

MacNaughtan, B., \& Farhat, I. A. (2008). Thermal methods in the study of foods and foods ingredients. In P. Gabbott (Ed.), Principles and applications of thermal analysis (chap. 9, pp. 330-402). Garsington Road: Blackwell Publishing.

Matuda, T. G., Parra, D. F., Lugao, A. B., \& Tadini, C. C. (2005). Influence of vegetable shortening and emulsifiers on the unfrozen water content and textural properties of frozen French bread dough. LWT - Food Science and Technology, 38(3), 275-280. http://dx.doi. org/10.1016/j.lwt.2004.06.001.

Matuda, T. G., Pessôa, P. A., Fo., \& Tadini, C. C. (2011). Experimental data and modeling of the thermodynamic properties of bread dough at refrigeration and freezing temperatures. Journal of Cereal Science, 53(1), 126-132.

Mora-Avilés, A., Lemus-Flores, B., Miranda-López, R., HernándezLópez, D., Pons-Hernández, J. L., Acosta-Gallegos, J. A., \& GuzmánMaldonado, S. H. (2007). Effects of common bean enrichment on nutritional quality of tortillas produced from nixtamalized regular and quality protein maize flours. Journal of the Science of Food and Agriculture, 87(5), 880-886. http://dx.doi.org/10.1002/jsfa.2801.

Osorio-Díaz, P., Agama-Acevedo, E., Bello-Pérez, L. A., Islas-Hernández, J. J., Gómez-Montiel, N. O., \& Paredes-López, O. (2011). Effect of endosperm type on texture and in vitro starch digestibility of maize tortillas. LWT - Food Science and Technology, 44(3), 611-615. http:// dx.doi.org/10.1016/j.lwt.2010.09.011.

Palacios-Fonseca, A. J., Vázquez-Ramos, J. C., \& Rodríguez-García, M. E. (2009). Physicochemical characterizing of industrial and traditional nixtamalized corn flours. Journal of Food Engineering, 93(1), 45-51. http://dx.doi.org/10.1016/j.jfoodeng.2008.12.030.

Ramírez-Moreno, E., Cordoba-Díaz, M., Sánchez-Mata, M. C., Marqués, C. D., \& Goñi, I. (2015). The addition of cladodes (Opuntia ficus indica L. Miller) to instant maize flour improves physicochemical and nutritional properties of maize tortillas. LWT-Food Science and Technology, 62(1), 675-681.

Rendón-Villalobos, J. R., Bello-Pérez, L. A. E., Agama-Acevedo, E., IslasHernández, J. J., Osorio-Díaz, P., \& Tovar, J. (2009). Composition and characteristics of oil extracted from flaxseed-added corn tortilla. Food Chemistry, 117(1), 83-87. http://dx.doi.org/10.1016/j. foodchem.2009.03.080.

Reyes-Moreno, C., Ayala-Rodríguez, A. E., Milán-Carrillo, J., MoraRochín, S., López-Valenzuela, J. A., Valdez-Ortiz, A., Paredes-López, O., \& Gutiérrez-Dorado, R. (2013). Production of nixtamalized flour and tortillas from amarantin transgenic maize lime-cooked in a thermoplastic extruder. Journal of Cereal Science, 58(3), 465-471. http://dx.doi.org/10.1016/j.jcs.2013.09.008.

Ruiz-Gutiérrez, M. G., Quintero-Ramos, A., Meléndez-Pizarro, C. O., Talamás-Abbud, R., Barnard, J., Márquez-Meléndez, R., \& LardizábalGutiérrez, D. (2012). Nixtamalization in two steps with different calcium salts and the relationship with chemical, texture and thermal properties in masa and tortillas. Journal of Food Process Engineering, 35(5), 772-783. http://dx.doi.org/10.1111/j.1745-4530.2010.00627.x.

Sánchez-Madrigal, M. Á., Quintero-Ramos, A., Martínez-Bustos, F., Meléndez-Pizarro, C. O., \& Ruiz-Gutiérrez, M. G. (2014). Effect of different calcium sources on the antioxidant of tortilla chips from extruded and nixtamlaized blue corn (Zea mays L.) flours. Food 
Science and Technology, 34(1), 143-149. http://dx.doi.org/10.1590/ S0101-20612014000100021.

Sefa-Dedeh, S., Cornelius, B., Sakyi-Dawson, E., \& Afoakwa, E. O. (2003). Application of response surface methodology for studying the quality characteristics of cowpea-fortified nixtamalized maize. Innovative Food Science \& Emerging Technologies, 4(1), 109-119. http://dx.doi.org/10.1016/S1466-8564(02)00070-X.

Serventi, L., Carini, E., Curti, E., \& Vittadini, E. (2009). Effect of formulation on physicochemical properties and water status of nutritionally enhanced tortillas. Journal of the Science of Food and Agriculture, 89(1), 73-79. http://dx.doi.org/10.1002/jsfa.3412.

Stone, H., Bleibaum, R. N., \& Thomas, H. A. (2012). Sensory evaluation practices (4th ed.). San Diego: Elsevier Academic Press.

Vaca-García, V. M., Martínez-Rueda, C. G., Mariezcurrena-Berasain, M. D., \& Domínguez-López, A. (2011). Functional properties of tortillas with triticale flour as a partial substitute of nixtamalized corn flour. LWT - Food Science and Technology, 44(6), 1383-1387. http://dx.doi.org/10.1016/j.lwt.2011.01.024.

Valderrama-Bravo, C., López-Ramírez, Y., Jiménez-Ambriz, S., OaxacaLuna, A., Domínguez-Pacheco, A., Hernández-Aguilar, C., \& Moreno-Martínez, E. (2015). Changes in chemical, viscoelastic, and textural properties of nixtamalized dough with nejayote. $L W T$ - Food
Science and Technology, 61(2), 496-502. http://dx.doi.org/10.1016/j. lwt.2014.12.038.

Vázquez-Carrillo, M. G., Santiago-Ramos, D., Gaytán-Martínez, M., Morales-Sánchez, E., \& Guerrero-Herrera, M. J. (2015). High oil content maize: Physical, thermal and rheological properties of grain, masa, and tortillas. LWT - Food Science and Technology, 60(1), 156161. http://dx.doi.org/10.1016/j.lwt.2014.07.043.

Vittadini, E., Clubbs, E., Shellhammer, T. H., \& Vodovotz, Y. (2004). Effect of high pressure processing and addition of glycerol and salt on the properties of water in corn tortillas. Journal of Cereal Science, 39(1), 109-117. http://dx.doi.org/10.1016/j.jcs.2003.08.002.

Wood, P. J. (2007). Cereal $\beta$-glucans in diet and health. Journal of Cereal Science, 46(3), 230-238. http://dx.doi.org/10.1016/j.jcs.2007.06.012.

Zhao, Q., Hu, X., Guo, Q., Cui, S. W., Xian, Y., You, S., Chen, X., Xu, C., \& Gao, X. (2014). Physicochemical properties and regulatory effects on $\mathrm{db} / \mathrm{db}$ diabetic mice of $\beta$-glucans extracted from oat, wheat and barley. Food Hydrocolloids, 37, 60-68. http://dx.doi.org/10.1016/j. foodhyd.2013.10.007.

Zhu, F., Du, B., \& Xu, B. (2016). A critical review on production and industrial applications of beta-glucans. Food Hydrocolloids, 52, 275288. http://dx.doi.org/10.1016/j.foodhyd.2015.07.003. 